\title{
T lymphocytes against solid malignancies: winning ways to defeat tumours
}

\author{
Ignazio Caruana ${ }^{1, \S}$, Luca Simula ${ }^{1,2, \S}$, Franco Locatelli ${ }^{1, \#}$ and Silvia Campello ${ }^{2,3, \#, *}$ \\ ${ }^{1}$ Dept. of Pediatric Onco-Hematology and cell and gene therapy, IRCCS Bambino Gesù Children's Hospital, Rome, Italy. \\ ${ }^{2}$ Dept. of Biology, University of Rome Tor Vergata, Rome, Italy. \\ ${ }^{3}$ IRCCS, Santa Lucia Foundation, Rome, Italy. \\ §,\# These authors contributed equally to this work. \\ * Corresponding Author: \\ Silvia Campello, Department of Biology, University of Rome Tor Vergata, Via della Ricerca Scientifica, 00133 Rome, Italy; Phone: \\ +390672594227; E-mail: silvia.campello@uniroma2.it
}

ABSTRACT In the last decades, a novel field has emerged in the cure of cancer, by boosting the ability of the patient's immune system to recognize and kill tumour cells. Although excellent and encouraging results, exploiting the effect of genetically modified T cells, have been obtained, it is now evident that tumour malignancies can evolve several mechanisms to escape such immune responses, thus continuing their growth in the body. These mechanisms are in part due to tumour cell metabolic or genetic alterations, which can render the target invisible to the immune system or can favour the generation of an extracellular milieu preventing immune cell infiltration or cytotoxicity. Such mechanisms may also involve the accumulation inside the tumour microenvironment of different immune-suppressive cell types, which further down-regulate the activity of cytotoxic immune cells either directly by interacting with them or indirectly by releasing suppressive molecules. In this review, we will first focus on describing several mechanisms by which tumour cells may dampen or abrogate the immune response inside the tumour microenvironment and, second, on current strategies that are adopted to cope with and possibly overcome such alterations, thus ameliorating the efficacy of the current-in-use anti-cancer immuno-therapies. doi: $10.15698 /$ cst2018.07.148

Received originally: 29.04.2018

in revised form: 10.07.2018,

Accepted 11.07.2018,

Published 26.07.2018.

Keywords: cancer immuno-therapy, immune cell infiltration, tumour microenvironment, extracellular matrix, immune-suppression.
Abbreviations:
$C A R$ - chimeric antigen receptor,
$D C$ - dendritic cell,
ECM - extracellular matrix,
ILC - innate lymphoid cell,
MDSC - myeloid-derived suppressor cell,
MHC-major-histocompatibility
complex
$N K$ - natural killer,
OXPHOS-oxidative phosphorylation,
$S L O-$ secondary lymphoid organ,
TAMa - tumour-associated
macrophage,
$T C R-T$-cell receptor,
TIL - tumour infiltrating Tlymphocytes,
TME - tumour microenvironment,
Treg-regulatory $T$-cell.

\section{INTRODUCTION}

When a tumour mass starts growing in the body, T lymphocytes are activated inside secondary lymphoid organs (SLOs) and mount an immune response against immunostimulating tumour antigens presented by professional antigen presenting cells. This stimulation allows $T$ lymphocytes to leave SLOs, thus reaching the tumour mass and eliminating malignant cells. Although the capability of the immune system to prevent tumour growth may last for years, tumour cells may eventually escape immunesurveillance [1] and create a chronic tumour microenvironment (TME), which predisposes to the generation of highly-inefficient, "dysfunctional" T cells, with impaired metabolic activity and cytotoxic functionality [2].

In this Review, we will focus on the mechanisms by which alterations in the architecture of the TME predispose 
to a dysfunctionality of T cells, once inside the tumour, thus limiting their ability to cope with a growing number of cancer cells.

\section{THE SEVERAL IMMUNE SUBTYPES INSIDE THE TME}

Most subtypes of the innate and adaptive immune cells infiltrate into a solid tumour mass and can be generally divided for their pro- or anti-tumor role (Table 1). Tumourinfiltrating $\mathrm{T}$ lymphocytes are commonly known as TILs. Cytotoxic CD8+ TILs are major player in the immune response against tumour growth and their recognition of tumour-specific antigens allows killing of malignant cells through Fas ligand or perforin/granzyme pathways. Usually, helper CD4+ TILs mainly produce several inflammatory cytokines, which can support the activation and cytotoxicity of CD8+ T cells and of other pro-inflammatory immune cells [3]. However, a subgroup of CD4+ $T$ cells, the regulatory $T$ cells (Treg), play an anti-inflammatory and immunesuppressive role inside the TME, thus favouring tumour growth, by inhibiting dendritic cell (DC) presentation of tumour antigens to $T$ cells and by producing membranebound or soluble factors, which impair T-cell activation and cytotoxicity [4]. The role of tumour infiltrating B lymphocytes (TIBLS) in cancer progression is more debated. Although some reports indicate that TIBLs can have an antitumor effect, for example producing antibodies which fa- vour tumour cell recognition by phagocytic macrophages, they can also differentiate towards a regulatory phenotype (Bregs), which produce pro-tumor factors, such as lymphotoxin (which promotes neo-angiogenesis) and immune suppressive cytokines [5].

DCs are required to uptake and present tumourderived antigens to adaptive $\mathrm{T}$ cells into secondary lymphoid organs (SLOs). Therefore, their infiltration into tumour mass is required to mount an efficient adaptive immune response against tumours, and to sustain the generation of tumour-specific T lymphocytes for an efficient elimination of malignant cells [6]. Innate lymphoid cells (ILCS) are a large family of innate cells whose subdivision is very similar to that of $\mathrm{T}$ lymphocytes, although they lack antigen-specific receptors and are mainly activated in response to common innate signals. Indeed, among them, we can find cytotoxic natural killer (NK) cells (equivalent of CD8+ T lymphocytes) and helper-like ILCs, which further subdivide into ILC- $-1,-2$, and -3 (which are functionally similar to Th1, Th2 and Th17 CD4+ T cells, respectively) [7]. NK cells are cytotoxic cells which can recognize and kill tumour cells that lack the expression of major-histocompatibilitycomplex (MHC) molecules, and therefore cannot present antigens on cell surface, this rendering them invisible to cytotoxic CD8+ T cells [8]. Between regular $\alpha / \beta$ T lymphocytes and NK cells, a subgroup of T cells named $\gamma / \delta \mathrm{T}$ lym-

TABLE 1. Immune subtypes infiltrating solid tumors. List of innate and adaptive immune subtypes infiltrating solid tumour microenvironment. For each one, the pro- or anti-tumoral role (activity), the prevalent metabolism, and the main released factors -as soluble molecules or exposed on the cell surface, are reported.

\begin{tabular}{|c|c|c|c|}
\hline Cell type & Activity & Metabolism & $\begin{array}{l}\text { Released or surface factors } \\
\text { (pro-inflammatory / anti-inflammatory) }\end{array}$ \\
\hline CD8+ TILs & anti-tumoral & glycolytic & IFNY, TNF $\alpha$, IL2, GranzymeB, Perforin \\
\hline CD4+ TILS th1 & anti-tumoral & glycolytic & IFN $\gamma$, TNF $\alpha$, IL2 \\
\hline CD4+ TILS th2 & pro-tumoral & glycolytic & IL4, IL5, IL13, IL25, IL10 \\
\hline CD4+ TILS th17 & anti-tumoral & glycolytic & IL21, IL17a, IL17f, IL22 \\
\hline Tregs & pro-tumoral & oxidative & IL10, TGF $\beta$, IL35, CD39, CD73, IDO \\
\hline TIBLs & anti-tumoral & mainly glycolytic & IL2, IL4, TNF $\alpha$, IL22, IL6, IL15, GM-CSF \\
\hline Bregs & pro-tumoral & oxidative (?) & Lymphotoxin, IL10, TGF $\beta$, IL12, PDL1, FasL \\
\hline DCs & anti-tumoral & glycolytic & IL2, IL12, IFNץ, TNF $\alpha$, IL10, TGF $\beta$, IL6, IL4 \\
\hline NK cells & anti-tumoral & mainly glycolytic & IFNY, TNF $\alpha$, IL2, GranzymeB, Perforin \\
\hline ILCs & mixed & mixed & ILC $-1,-2,-3$ similar to th- $1,-2$ and -17 subsets \\
\hline MDCs & pro-tumoral & oxidative & Arginase, PGE2, IDO, TGF $\beta$, M-CSF \\
\hline TAM M1-like & anti-tumoral & glycolytic & IL6, IL12, IL23, TNF $\alpha$, Cxcl5, Cxcl9, Cxcl10, IL1 $\beta$, iNOS \\
\hline TAM M2-like & pro-tumoral & oxidative & IL10, TGF $\beta$, IL6, Arginase, VEGF, IL1 $\beta$ \\
\hline
\end{tabular}

Abbreviations: TILs: tumor-infiltrating-T-lymphocytes; TIBLs: tumor-infiltrating-B-lymphocytes; DCs: dendritic cells; NK: natural Killer; ILCs: innate lymphoid cells (other than NK cells); MDSCs: myeloid-derived-suppressor-cells; TAM: tumor-associated-macrophages; IDO: Indoleamine-2,3-dioxygenase; iNOS: inducible Nitric Oxide Synthase; VEGF: vascular endothelial growth factor. 
phocytes combine both innate and adaptive characteristics Their potent cytotoxic activity against bacteria, virus and tumours makes them particularly attractive for adoptive immunotherapy approaches. Differently from $\alpha \beta$ T cells, these cells recognize their ligands in an MHC-independent manner showing a significant reduced allo-reactivity as compared to $\alpha \beta$ T cells, this making them appealing for clinical translation $[9,10]$. Contrary to NK cells and $\gamma / \delta T$ lymphocytes, the role of other ILCs in cancer has only recently been discovered and few related data are available. However, it seems that ILC2 and ILC3 subtypes may favour tumour growth by secretion of specific immunesuppressive cytokines [7]. Similarly, myeloid-derivedsuppressor-cells (MDSCs) are pro-tumoral cells, producing factors that inhibit T-cell activity and also promote tumour growth by remodelling extracellular matrix and blood capillaries [11]. Last, macrophages can differentiate into different subtypes inside the TME, where they are known as tumor-associated macrophages (TAM). Briefly, an antitumor M1-type TAM can produce inflammatory cytokines and phagocyte tumour cells [12]. However, most TAMs have a pro-tumor $\mathrm{M} 2$-like phenotype, favouring tissue remodelling and angiogenesis and producing immune suppressive cytokines, which dampen T cell response [12].

It is worth noting that the amount and subtypes of immune cells present in TME may vary widely between different tumours. This heterogeneity has led to the development of a classification into "immune-desert", "immuneinflamed" and "immune-excluded" tumours [13], based on the quality and quantity of immune infiltrates. Immunedesert tumours show poor infiltration of $\mathrm{T}$ cells and are characterized by high number of myeloid suppressor cells, which also produce immune-suppressive cytokines. Immune-excluded tumours are characterized by a high amount of infiltrating immune cells, both immunesuppressive (pro-tumor) or cytotoxic (anti-tumor). However, these cells do not frequently penetrate inside the tumour parenchyma but remain in the surrounding stroma and therefore cannot efficiently kill malignant cells. Last, immune-inflamed tumors are characterized by high amounts of infiltrating $T$ cells, which efficiently reach tumour cells for their killing, and by abundant production of pro-inflammatory cytokines [13].

\section{THE FIRST SIDE OF THE COIN: TME IN SOLID MALIGNANCIES}

Tumours have been recognized as complex disorganized and chaotic organs, where cancer cells co-exist and coevolve with their stroma. The interface between malignant and non-transformed cells defines the TME $[1,14]$. The importance of TME for tumorigenesis is now widely recognized in both solid and haematological malignancies [15]. However, in solid tumours, the TME has a more relevant impact on tumour growth being able to offer protection with respect of the action of the immune system. During solid tumour development, the TME initiates to organize itself supporting tumour growth directly, but also erects chemical and physical barriers capable to defend the tu- mour from the activity of an intact immune system, thereby preventing cancer immune surveillance. In this context, TME appears to be a complex ecosystem containing a tight interstitial extracellular matrix (ECM), where various stromal, endothelial and inflammatory cells are recruited from the surrounding tissues. The interaction between these different components modulates phenotype and behaviour of the tumour and may affect cancer progression, as well as the formation of metastases [16-18]. Specifically, it has been reported that, in this environment, cancer cells show self-sufficiency in growth signals, resistance to programmed cell death, limitless replicative potential, and ability to induce angiogenesis, invasion, and metastasis formation $[19,20]$. Recently, the role of ECM in the regulation of many of these cellular responses has been recognized. ECM has a fundamental role in cell behaviour and fate, not only sustaining and interconnecting cells, but also influencing many cellular mechanics and functions, such as differentiation and migration, in both physiological and pathological conditions.

Cancer cells are also able to develop mechanisms to blunt detection and eradication by immune cells. These strategies include: i) a reduction of tumour immunogenicity, due to loss of expression of tumour-associated antigens or MHC class I molecules, ii) acquired DNA copy number alterations and oncogenic signaling -equipping them with an uncontrolled proliferative capacity and insensitivity to negative feedback from microenvironment, iii) an upregulation of cellular immune check-points - such as the programmed death ligand 1 (PDL1, which inhibits T-cell activation by stimulating PD-1 receptor on T-cell surface), indoleamine 2,3-dioxygenase, and finally iv) an altered metabolism producing a low $\mathrm{pH}$ and secretion of various metabolites, which inhibit the effector cell recruitment, persistence and activity [21-24]. In particular, tumour cells can evolve mechanisms which actively induce T-cell apoptosis, by up-regulating the expression of pro-apoptotic molecules on their surface, such as Galectin-1 [25], TRAIL (TNF-Related Apoptosis-Inducing Ligand) [26] and Fas Ligand (FasL) [27], which promote T-cell death by interacting with the corresponding receptors on T-cell surface. Moreover, in the TME, a competition for nutrient availability is frequently observed between tumour and immune cells. Although cancer stem cells may rely on an oxidative metabolism for their survival [28], in most cases, tumour cells switch their metabolism from oxidative phosphorylation (OXPHOS) to glycolysis even in presence of high-oxygen tension to sustain a high proliferation rate (a process known as Warburg effect [29]). Since this switch is also observed for T-cell upon activation [30], this generates a competition for glucose availability between these cell types. However, tumour cells frequently win the battle probably because of a faster glycolytic rate in tumour cells [31] and a further down-regulation of glycolytic flux in immune cells by tumour cells-released extracellular lactate $[32,33]$. As mentioned above, tumour cells may upregulate PDL1 on their surface [34, 35], which engages the PD-1 receptor on activated T lymphocytes, thereby activating a signalling cascade that inhibits $\mathrm{PI} 3 \mathrm{~K} / \mathrm{Akt} / \mathrm{mTOR}$ axis 
[36], essential to induce glycolysis in effector T cells. Interestingly, while these considerations apply to effector cytotoxic T cells, immune Tregs actively maintain an OXPHOSbased catabolism instead of glycolysis $[37,38]$. This confers to Tregs a metabolic advantage compared to effector/cytotoxic T cells [39]. To further increase the suppressive TME, several other molecules are secreted by tumour cells and by other immune-cells recruited by the tumour. For example, in a preclinical study it has been reported how the secretion of prostaglandin-E2 (PGE2) and adenosine by endothelial tumour-associated cells selectively kills effector $T$ cells and how their inhibition resulted in downregulation of FasL and CD8 T-cell influx [40].

Besides Tregs, other cells of the immune system are recruited to the TME as MDSC, TAMs and neutrophils. All these cells boost the tumour survival-promoting environment [41-44] i) by reducing, for example, L-arginine concentration, which is required for long-lasting survival of infiltrating memory $\mathrm{T}$ cells [45], ii) by producing reactive nitrogen species that hamper T-cell proliferation and function, and iii) by expressing molecules on their surface capable to activate check-point inhibitor receptors expressed by T lymphocytes (Galactin9) [44-47]. The described TME with all these elements is able to regenerate and stabilize itself.

Making matters worse, tumour cells and their TME are able to initiate and promote angiogenesis. This phenomenon induces the formation of new vessels capable to support blood supply to the tumour; the resulting vessel network is leaky, chaotically organized, immature, thin-walled and ill-perfused. Such an aberrant angiogenesis contributes to the maintenance of the pro-tumorigenic and immunosuppressive TME and profoundly influences how cancer cells escape the anti-cancer immune surveillance, metastasize, and respond to immunotherapy [48-51]. This occurs by preventing, for instance, a correct inflow of the immune system to the tumour site. Furthermore, this reduced influx of nutrients and gaseous exchange strongly decreases the quality and number of effector cells in the TME, thus increasing tumour growth as well as the possibility of invasiveness of tumour cells $[52,53]$. For these reasons, the TME represents an inhospitable and inaccessible environment for effector immune cells, due to the generation of a hypoxic atmosphere, low nutrient supply and a high concentration of metabolic acids. These conditions facilitate the selection of cancer cells with genetic and epigenetic alterations, which enhance their aggressiveness. In the meanwhile, they increase activation-induced autophagy processes and stress in immune cells, which makes cytotoxic lymphocytes unable to proliferate and produce cytokines $[54,55]$. Hypoxia in the TME can dampen T-cell functionality through different mechanisms, such as: i) by exacerbating glucose deprivation, ii) by reducing cytosolic levels of $\mathrm{Ca}^{2+}$, which is essential for cytokine production [56], or iii) by promoting excessive formation of reactive oxygen species [57]. In addition, it has been proven that hypoxia can up-regulate PDL1 on tumour cells [58], which in turn dampens T-cell functionality by interacting with the inhibitory receptor PD1 on T-cell surface. Importantly, hypoxia and acidosis, besides reducing the cytotoxic activity of tumour-infiltrating effector $T$ cells, also facilitate the attraction and/or development of immuno-suppressive immune cells, and hamper delivery of chemotherapeutics and immunotherapeutic entities, as well as cancer cell killing in response to radio/chemotherapy and immunotherapy.

The recruitment of particular cell types into TME and their contact with tumour cells has been described to produce an immuno-suppressive microenvironment, for example, due to the secretion of PGE2 and adenosine.

To further protect itself, the tumour establishes strong interactions with the corrupted stromal cells, by also initiating the production of a physical barrier remodelling the ECM. This is achieved, for example, by the modification of soluble factors (cytokines, growth factors, hormones), type of cells, and structural proteins (collagens, laminins, fibronectins, proteoglycans and hyaluronans), with the latter altering the normal stiffness and adhesion strength of the ECM [59-61]. In summary, these biomechanical changes involve not only cancer cells but also their ECM and the entire TME components. The increase of ECM stiffness, for instance, promotes cancer invasion and progression [62]. Moreover, the recruitment of other cells including fibroblasts, myofibroblasts, granulocytes, macrophages, mesenchymal stem cells and lymphocytes in the surrounding stroma, could also be responsible for the hard consistency of tumours at a macroscopic scale. Also, cancer-associated fibroblasts (CAFs) reorganize the stroma by secreting new ECM elements and enzymes that covalently cross-link collagen fibres and pull the collagen network closer together.

\section{THE OPPOSITE FACE OF THE COIN: THE STRESS OF T LYPMPHOCYTES IN THE ATTEMPT TO SURVIVE, REACH AND KILL TUMOUR CELLS}

An efficient T-cell response depends on several aspects related to both tumour cells, as described, as well as on factors associated with T-cell activation and functionality. In order to be effective, $\mathrm{T}$ lymphocytes require three signals: i) the interaction of the antigenic peptide-MHC complex with the T-cell receptor (TCR), ii) the binding with the co-stimulatory or co-inhibitory ligand, provided by antigenpresenting cells, and iii) the stimulation/proliferation mediated by extracellular cytokines such as interleukin (IL)-2 and IL-15 [63]. Among these signals, the second one determines the promotion or inhibition of T-cell cytokine production and effector function; appropriate co-inhibitory signals dampen inflammation to avoid tissue damage due to an excessive immune reaction, whereas durative and excessive co-inhibitory signals lead to T-cell hyporesponsiveness [64]. Then, in many cases, tumour antigens are weakly immunogenic self-molecules and most tumourspecific T cells have low precursor frequencies and low TCR affinity. This phenomenon occurs because $T$ cells with high avidity against self-molecules, including also tumour selfantigens, are normally deleted during thymic T cell education [65]. In addition, it has been proven that the antigen presentation process is strongly impaired in TME, this leading to insufficient priming and boosting of $\mathrm{T}$ lymphocytes 
[66]. As mentioned above, down-regulation of $\mathrm{MHC}$ proteins makes tumour cells "invisible" to infiltrating effector T cells, this resulting into a dysfunction of their anti-tumour activity. This effect is further enhanced by a lack of costimulatory molecules in several solid and haematopoietic tumours [67].

The presence of anti-inflammatory soluble factors released by tumour-associated corrupted cells, such as IL-10, transforming-growth-factor- $\beta$ (TGF $\beta), \quad$ cyclooxygenase- 2 (COX2), inducible nitric oxide synthase (iNOS) and PGE2, induces the expression of several negative ligands (FasL, PDL1, PDL2, Galactin 9, ect.) on the cells present inside the TME, including T lymphocytes, whose response is therefore inhibited (Table 2). T lymphocytes infiltrating the TME may thus undergo functional exhaustion. This "exhausted" signature is progressively acquired with time, mainly due to a continuous stimulation of the TCR, followed by a progressive increase of expression of co-inhibitory receptors (PD-1, LAG-3, TIM3, CTLA-4, BTLA and TIGIT) [68-71], and by a decrease of cytokine production and proliferation potential. All these modifications make exhausted $T$ cells unable to differentiate back into functional memory cells, even if antigen stimulation is removed [72]. Interestingly, this "exhausted" state is hard-wired to epigenetic modifications into the T cell genome. Given the frequent chronic nature of a cancer, it is not surprising that exhausted $T$ cells have been found in several tumours [73-75]. In this scenario, also TAMs, MDSC [76] and Treg [77] facilitate the generation of exhausted cells in the TME [78]. Also, the finetuning control of ionic balance in the TME is an additional check-point for an efficient T-cell functionality. Indeed, potassium ions, released by necrotic cells in the extracellular milieu, can be internalized by infiltrating $T$ cells, thus inhibiting their effector functions by downregulation of the Akt/mTOR signalling, downstream of TCR stimulation [79]. Similarly, tumour-infiltrating human T cells expressing high levels of the calcium channel Kv1.3 can sustain their calcium influx upon TCR stimulation also in environment with low-calcium levels, thus improving their cytotoxicity against tumour cells [80]. The presence of an immunesuppressive environment and the absence of adequate chemotactic factors significantly reduce recruitment of new immune cells from the periphery or from lymphatic organs. To migrate towards a particular tissue, immune cells need the presence of a particular environment produced by cytokines or chemokines, these creating the in situ correct attractive chemical gradient. Every TME produces a specific offset of cytokines and chemokines capable to attract or repel different cell types. Chemokine gene expression profiles and immune cell infiltration have been investigated in different tumour types [81-83]. To hinder $T$ cell migration to the tumour site, tumour-derived chemokines may misdirect activated $T$ cells to the tumour surrounding stromal cells [84], and cancer cells can further post-transcriptionally modify their chemokine expression profile. For example, CCL2 nitrosylation can reduce its chemoattractive effect on effector $T$ cells, but not on MDSCs [85].

Furthermore, the presence of a compact ECM increases the incapacity of $\mathrm{T}$ lymphocytes to recognise and kill tumour cells, since $T$ lymphocytes need to actively infiltrate the TME to reach the neoplastic cells. Invasion is an active

TABLE 2. Factors regulating CD8+ TIL functionality inside the TME. List of molecules that can inhibit, or sustain, tumour-infiltrating-Tlymphocyte (TIL) functionality inside the tumour microenvironment. The corresponding receptors on TIL surface of the indicated checkpoint molecules are reported in brackets.

\section{TILs inhibitory factors}

Soluble cytokines

IL-10, TGFß (from myeloid cells and Tregs)

Inhibitory Check-point

PD-L1/2 (from myeloid and tumor cells, bind PD-1), B7-H4 (unknown target), CD276 (binds CTLA4)

Metabolites

Oxide, IDO, COX2 metabolites, PGE2 (from myeloid and tumor cells), adenosine (from myeloid cells and Tregs)

TILs co-stimulatory factors

Soluble cytokines

Stimulatory Check-point

Metabolites
IL2, IL7, IL15, IFNY, TNFa (from pro-inflammatory myeloid and lymphoid cells)

CD86/80 (bind CD28), CD70 (binds CD27), CD137L (binds CD137), CD235 (binds CD134), CD58 (binds CD2), B7 (binds CD28), OX40L (binds OX40), 4-1BBL (binds 4-1BB)

arginine (memory survival), fatty acids (oxidative metabolism)

Abbreviations: TILs: tumor-infiltrating-T-lymphocytes; IDO: Indoleamine-2,3-dioxygenase; COX2: cyclo-oxigenase2; PGE2: Prostaglandin E2. 
process in which secretion of particular enzymes is needed to degrade the ECM elements. Several groups, including our own one, reported how this invasion capacity is reduced in patients after high dose chemotherapy and after adoptive $T$ cell transfer, in both cell and gene therapy settings [86]. In the last years, different researches focused on the optimization of chemotherapy regimens in combination with immunotherapies $[87,88]$, such as Treg depletion $[89,90]$, blockage of check-point inhibitors [91, 92], antiangiogenesis treatment $[93,94]$, use of oncolytic virotherapy $[95,96]$ and gene modification of T lymphocytes [86, 97], in order to improve the penetration of T lymphocytes or other effector cells. This aspect will be addressed in the following paragraph.

\section{PRE-CLINICAL AND CLINICAL DATA ON REDUCING T-} CELL STRESS AND IMPROVING ANTI-TUMOUR ACTIVITY In the last two to three decades, the development of a new field of research has focused on advanced anti-cancer immunotherapies. Strategies include monoclonal antibodies, adoptive cell transfer, check-point inhibitors, vaccine therapies, oncolytic therapies and gene modification of effector cells, all these approaches showing remarkable longterm efficacy in patients with various types of cancers [98103]. Although conventional therapies, such as radiation and chemotherapy, induce positive responses in the majority of patients, relapse and resistance often occur in patients after prolonged treatment [104]. The strategies developed so far have focused their attention on implementation of tumour targeting. Recently, several pre-clinical and clinical studies have highlighted how most of the pitfalls observed during cancer treatment, in particular in the setting of solid tumours, are not only related to the presence of heterogeneous subpopulations of cancer cells, but also to the development and/or recruitment during tumorigenesis of particular cell types and chemical-physical barriers, which are instrumental to the pathologic manifestation of cancer $[105,106]$.

Clinical trials underline how the presence of adequate and functional $T$ cells within tumours correlates with favourable clinical outcome. Several studies in animal models have been carried out in order to fully understand how T-cell infiltration can be enhanced to promote tumour rejection, or to prevent recurrence [107-109]. The everdeeper knowledge of the TME and its constitutive elements, and development of multidisciplinary approaches are laying the foundations for technologies that, one step at a time, are trying to tackle the problem of improving the invasive capacity of T lymphocytes, while improving both their ability to survive and their tumour specificity.

Immunotherapies targeted to counteract the mechanisms of tumour-induced T-cell dysfunction have successfully provided persistent clinical benefits in patients with advanced cancer. Most recently, they have focused on immune check-point blockade in order to block the activation of co-inhibitory receptors, or to reduce their levels on the surface of exhausted T cells in cancer patients. Most of these therapies proved to be successful by increasing T-cell functionality inside the TME by restoring their cytokine production and/or cytotoxic activity. Up to now, several check-point inhibitors are currently tested in clinical trials [110] including: combinations of PD1 or of its ligand PDL1, CTLA4 and LAG3 signalling inhibitors [100, 101, 111-113], or agents promoting the immune response with CD40/CD40L, CD137, OX40 and GITR stimulation/engagement [114].

Up to now several pre-clinical and clinical studies have shown the feasibility to redirect $T$ lymphocytes on cancer cells through chimeric antigen receptors (CARs) in order to guarantee the specificity of T lymphocytes, overcoming the problem of human $\mathrm{MHC}$ protein down-regulation and the lack of costimulatory molecules [115]. A typical CAR consists of a single-chain variable fragment (scFv) linked to an intracellular signalling domain, derived normally from T cells, and more recently also from NK cells $[116,117]$. A more advanced generation of these molecules is being engineered to recapitulate the costimulatory events that occur upon TCR triggering to fully activate T lymphocytes. Signaling domains derived from T-cell costimulatory receptors are thus directly incorporated in tandem with the TCR co-receptor $\mathrm{CD} 3 \zeta$ chain. Intra-cytoplasmic signaling domains of CD28, CD134 (OX40), CD137 (4-1BB), inducible costimulator (ICOS), CD27, DAP10 or CD244 (2B4) in various combinations have been used to construct second and third-generation CARs [118]. After binding to tumour antigen through the SCFv, the CAR activates T cells in an antigen-specific and MHC-independent manner, inducing lysis of the engaged target cells through granzyme-B and perforin pathways. Clinical trials with CAR T therapy have shown incredible efficacy in patients with acute lymphoblastic leukaemia, with a complete response rate of nearly $90 \%$ un patients who had already failed several lines of conventional therapies, including allogeneic hematopoietic stem cell transplantation [119]. However, attempts to apply CAR T therapy to solid tumours has been less successful [120], and extensive efforts have been devoted to increasing CAR T-cell activity inside solid tumours, as well as their target specificity. For example, engineering CAR T cell to produce cytokines such as IL-7 and CCL19 have proved to increase their infiltration into solid tumour mass, leading to complete regression of pre-established tumours and prolonging survival in mice [121].

Several pre-clinical studies brought forward new strategies that can be applied to increase the infiltration of $T$ cells, taking advantage of the negative feedback present in the TME, and producing particular factors capable to boost their persistence, as well as recruiting the innate immune system and inflammatory components. We proved that the T lymphocytes overexpression of heparanase, one of the enzymes involved in the ECM modelling, significantly increased the capacity to degrade the ECM, thus resulting in enhanced tumour infiltration and antitumor activity [86]. Another updated strategy to implement T-cell infiltration is that based on the use of oncolytic viruses, which are able to infect and kill only tumour cells. Unfortunately, although highly promising in vitro [107], it did not show the expected results in clinical trials. Indeed, 
our group proposed the possibility to further arm the oncolytic therapy with chemokines and cytokines and to combine it with a CAR T-cell approach. The results of this strategy underline how this combinatory therapy is able to improve significantly tumour eradication and T-cell persistence [96]. Based on this data, a growing number of clinical trials proposed to evaluate the clinical efficacy of: checkpoint inhibitors of soluble mediators (IDO, A2aR, CSF1R, IL10 or TGF $\beta$ ), agonistic antibodies targeting and activating receptors on T cells, anti-tumour vaccines $[122,123]$ and adoptive transfer of CAR T cells [124, 125].

Furthermore, different groups investigate also the possibility to manipulate the TME chemokine profile in order to recruit sufficient numbers of effector cells into the tumour sites. In this regard, interesting data were produced with T,cell chemo-attractants, such as CCL4, CCL5, CCL21, CXCL10, TNF $\alpha$, IFN $\beta$ and TNFSF14 [96, 126-129]. Nevertheless, alternative strategies increasing $T$ cell infiltration into the tumour mass is one of the main challenges that researchers will still have to face in the future. In this way, unconventional and unexpected regulators of these pro- cesses, such as mitochondria-dependent myosin fuelling of T-cell migration (see next paragraph for further details) $[130,131]$, could unmask additional therapeutic opportunities to be exploited. In addition, new strategies, to be developed in future, could consider acting on satisfying the metabolic requirements of $T$ cells inside the TME, because of the frequent low nutrient availability and hypoxic conditions. According to this hypothesis, several encouraging results have been recently obtained, such as for example, forcing $T$ cells to use metabolites alternative to glucose, as fatty acids [132] (Fig. 1).

In recent years, several studies have highlighted the role of mitochondria in regulating several key processes in $T$ cells. It has long been recognized that, while effector $T$ cells upregulate glycolysis to quickly produce adenosine triphosphate and to generate precursors for biosynthesis of macromolecules [133], memory T cells mainly rely on mitochondria-based oxidative metabolism, sustained at least in part by fatty acid oxidation [134]. Interestingly, the morphology of the mitochondrial network is tightly linked to the cell metabolic status and it can actively control it.

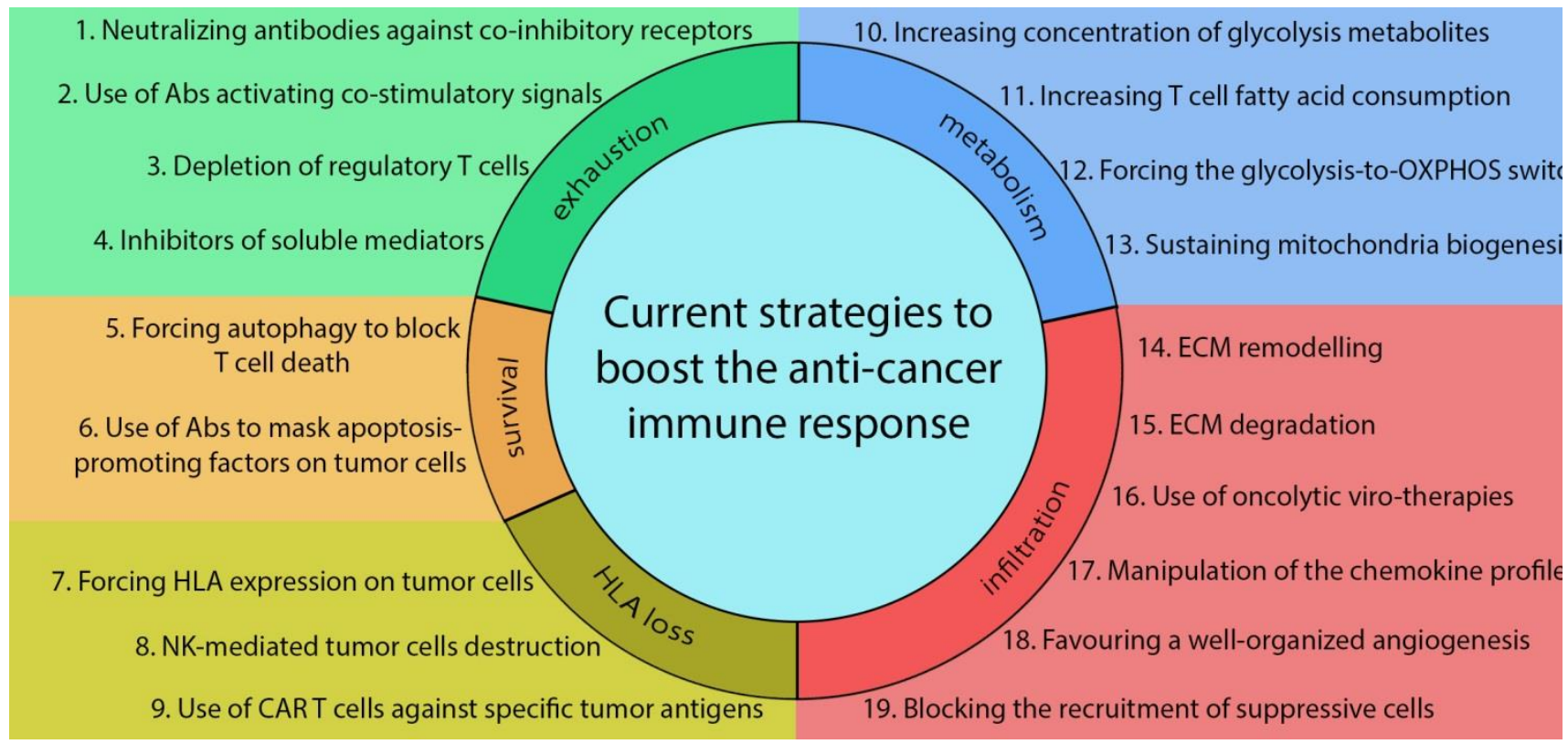

FIGURE 1: Current strategies to increase anti-cancer immune responses. The panel summarizes current strategies adopted in clinical trials or in basic research to increase the efficacy of immune-therapies against solid malignancies. Acting on T-cell exhaustion, researchers are currently testing the possibility to use soluble antibodies to neutralize co-inhibitory receptors (1) or to activate co-stimulatory signals on T cells (2). Other approaches involve depletion of immune suppressive Tregs (3) or the inhibition of soluble mediators produced by immune suppressive populations (4). Moreover, strategies could be adopted to prevent T-cell death inside the TME, by forcing autophagy in T cells (5) or by inhibiting the interaction between apoptosis-promoting factors on the tumour cell surface with apoptosis receptors on T cells using soluble neutralizing antibodies (6). In those cases, in which tumor cells evade the immune response due to a lack of antigen presentation, it is possible to force HLA expression on tumor cells (7) or to exploit the ability of NK cells to recognize and kill HLA-negative cells (8). Very recently, engineered CAR T cells have been used for their ability to kill tumour cells expressing specific antigens (10). Moreover, T cell functionality inside the TME may be increased through the modulation of its metabolism by increasing glycolysis metabolite concentration in the TME (10), by forcing T cells to utilize alternative substrates, such as fatty acids (11) or OXPHOS substrates (12), or by directly sustaining their mitochondria biogenesis and oxidative metabolism (13). Finally, several approaches are currently adopted to increase T-cell infiltration into the TME by forcing the expression of specific molecules by T cells, which can thus remodel (14) or completely degrade (15) the extracellular matrix (ECM), also by means of oncolytic-viruses (16). In addition, T-cell infiltration can be increased by modifying the chemokines expressed into the TME (17) or favouring a well-organized angiogenesis (18), which increases the ability of T cells to invade the tumour-surrounding stroma. By contrast, modulation of the chemokine profile could be used to prevent recruitment of suppressive immune populations into the TME (19). See text for details. 
Indeed, pharmacological manipulations favouring mitochondria elongation and OXPHOS activity, on in vitro isolated T cells, have been shown to reprogram T cells towards a memory phenotype, thus favouring their longterm survival and increasing their anti-tumour function [135]. In addition, forcing $T$ cells to utilize alternative pathways, instead of glycolysis, may favour their survival in glucose-deprived TME. In this way, increasing mitochondria-based fatty acid utilization could increase T-cell functionality inside the tumour [132]. In addition, a recent paper shows that TILs undergo downregulation of mitochondrial mass inside the TME [136]. Interestingly, the chronic antigen stimulation inside the TME leads to upregulated Akt levels, which, in turns, repress the activity of peroxisome proliferator-activated receptor gamma coactivator $1 \alpha,(P G C-1 \alpha)$ the master regulator of mitochondrial biogenesis. Therefore, dysregulation of mitochondrial oxidative metabolism, shut-down by hypoxia, has a strong negative effect on TILs functionality [136]. Besides regulating Tcell metabolism, mitochondria have also been implicated in T-cell migration, proliferation and apoptosis, all key aspects for an optimal T-cell anti-tumour response. We demonstrated that dynamin-related protein 1 (Drp1)-dependent mitochondria remodelling is crucial to sustain T-cell chemotaxis [130] and we have clues that it also controls extravasation towards a solid tumour mass. Moreover, Drp1mediated fission of mitochondrial network is essential for the redistribution of these organelles to daughter cells during cell division [137] and, in the absence of this process, the clonal expansion of T cells upon activation is strongly impaired (unpublished personal results). Therefore, modulation of mitochondrial dynamics may represent an important tool, in the future, to increase T-cell invasiveness and expansion into solid malignancies, in addition to modulate their energy utilization. This could become highly interesting, particularly for those "immune-excluded" tumours, where immune cells do not efficiently infiltrate into the tumour mass.

Mitochondria are also responsible for the release of cytochrome-C (cyt-C) in the cytosol during apoptosis. Although this process has long been investigated in cancer cells [138], we recently demonstrated that the morphology of the mitochondrial network tightly regulates also the physiological T-cell Activation-Induced Cell Death (AICD), a process normally involved in the shut-down of the immune response and exploited by tumours to kill them in the TME

\section{REFERENCES}

1. Dunn GP, Bruce AT, Ikeda H, Old LJ, Schreiber RD (2002). Cancer immunoediting: from immunosurveillance to tumor escape. Nat Immunol 3(11): 991-998. doi: 10.1038/ni1102-991

2. Wherry EJ, Kurachi M (2015). Molecular and cellular insights into $T$ cell exhaustion. Nat Rev Immunol 15(8): 486-499. doi: $10.1038 /$ nri3862

3. Hadrup S, Donia M, Thor Straten P (2013). Effector CD4 and CD8 T cells and their role in the tumor microenvironment. Cancer Microenviron 6(2): 123-133. doi: 10.1007/s12307-012-0127-6
[139], by promoting cyt-C release [140]. Indeed, the high rate of effector T-cell apoptosis inside the TME, due to chronic antigen stimulation, is one of the main obstacles for an efficient immune-response against solid malignancies. Again, engineering in vitro manipulated $\mathrm{T}$ cells to overcome this mitochondria-based processes could represent a novel approach to increase T-cell survival in the TME, and promising results have been recently obtained in this direction [141, 142]. At last, during T-cell stimulation, the autophagic machinery has important roles for an optimal $T$ cell functionality. For example, it is essential to sustain Tcell survival and proliferation and it also controls the generation of long-lived memory $T$ cells (see [143] for a review). Interestingly, we recently demonstrated that autophagy inhibition is necessary and strictly regulated to allow the onset of AICD, while forcing its activation prevents T-cell death [140]. Whether modulation of autophagy could be exploited to overcome the high rate of apoptosis in TME infiltrating T cells is a still an unexplored field, but it may represent another promising tool for future therapeutic purposes.

Overall, this large mass of data suggests that additional and completely new targets in T cells have been unmasked in crucial cellular processes and organelles, which could be exploited in the future to boost anti-cancer $\mathrm{T}$ cell response.

\section{ACKNOWLEDGMENTS}

This work was funded by AIRC Foundation ("MoTIs" IG 19826 grant) to SC.

\section{CONFLICT OF INTEREST}

The authors declare no conflict of interest.

\section{COPYRIGHT}

(C) 2018 Caruana et al. This is an open-access article released under the terms of the Creative Commons Attribution (CC BY) license, which allows the unrestricted use, distribution, and reproduction in any medium, provided the original author and source are acknowledged.

Please cite this article as: Ignazio Caruana, Luca Simula, Franco Locatelli and Silvia Campello (2018). T lymphocytes against solid malignancies: winning ways to defeat tumours. Cell Stress 2(8): 200-212. doi: 10.15698/cst2018.07.148

4. Takeuchi $Y$, Nishikawa $H$ (2016). Roles of regulatory $T$ cells in cancer immunity. Int Immunol 28(8): 401-409. doi: 10.1093/intimm/dxw025

5. Yuen GJ, Demissie E, Pillai S (2016). B lymphocytes and cancer: a love-hate relationship. Trends Cancer 2(12): 747-757. doi: 10.1016/j.trecan.2016.10.010

6. Gardner A, Ruffell B (2016). Dendritic Cells and Cancer Immunity. Trends Immunol 37(12): 855-865. doi: 10.1016/j.it.2016.09.006 
7. Vallentin B, Barlogis V, Piperoglou C, Cypowyj S, Zucchini N, Chéné M, Navarro F, Farnarier C, Vivier E, Vély F (2015). Innate Lymphoid Cells in Cancer. Cancer Immunol Res 3(10): 1109-1114. doi: 10.1158/2326-6066.CIR-15-0222

8. Morvan MG, Lanier LL (2016). NK cells and cancer: you can teach innate cells new tricks. Nat Rev Cancer 16(1): 7-19. doi: $10.1038 /$ nrc. 2015.5

9. Lawand M, Déchanet-Merville J, Dieu-Nosjean MC (2017). Key Features of Gamma-Delta T-Cell Subsets in Human Diseases and Their Immunotherapeutic Implications. Front Immunol 8(761. doi: 10.3389/fimmu.2017.00761

10. Capsomidis A, Benthall G, Van Acker HH, Fisher J, Kramer AM, Abeln Z, Majani Y, Gileadi T, Wallace R, Gustafsson K, Flutter B, Anderson J (2018). Chimeric Antigen Receptor-Engineered Human Gamma Delta T Cells: Enhanced Cytotoxicity with Retention of Cross Presentation. Mol Ther 26(2): 354-365. doi: 10.1016/j.ymthe.2017.12.001

11. Umansky V, Blattner C, Gebhardt C, Utikal J (2016). The Role of Myeloid-Derived Suppressor Cells (MDSC) in Cancer Progression. Vaccines 4(4). doi: 10.3390/vaccines 4040036

12. Noy R, Pollard JW (2014). Tumor-associated macrophages: from mechanisms to therapy. Immunity 41(1): 49-61. doi: 10.1016/j.immuni.2014.06.010

13. Chen DS, Mellman I (2017). Elements of cancer immunity and the cancer-immune set point. Nature 541(7637): 321-330. doi: $10.1038 /$ nature21349

14. Balkwill F, Mantovani A (2001). Inflammation and cancer: back to Virchow? Lancet 357(9255): 539-545. doi: 10.1016/S01406736(00)04046-0

15. Egeblad M, Nakasone ES, Werb Z (2010). Tumors as organs: complex tissues that interface with the entire organism. Dev Cell 18(6): 884-901. doi: 10.1016/j.devcel.2010.05.012

16. Discher DE, Janmey $P$, Wang YL (2005). Tissue cells feel and respond to the stiffness of their substrate. Science 310(5751): 11391143. doi: 10.1126/science. 1116995

17. Bonnans C, Chou J, Werb Z (2014). Remodelling the extracellular matrix in development and disease. Nat Rev Mol Cell Biol 15(12): 786801. doi: $10.1038 / \mathrm{nrm} 3904$

18. Stewart DA, Cooper CR, Sikes RA (2004). Changes in extracellular matrix (ECM) and ECM-associated proteins in the metastatic progression of prostate cancer. Reprod Biol Endocrinol 2(2. doi: 10.1186/1477-7827-2-2

19. Lu P, Weaver VM, Werb Z (2012). The extracellular matrix: a dynamic niche in cancer progression. J Cell Biol 196(4): 395-406. doi: $10.1083 /$ jcb. 201102147

20. Hanahan D, Weinberg RA (2000). The hallmarks of cancer. Cell 100(1): 57-70. doi: 10.1016/s0092-8674(00)81683-9

21. Reeves $E$, James $E$ (2017). Antigen processing and immune regulation in the response to tumours. Immunology 150(1): 16-24. doi: 10.1111/imm.12675

22. Bhatia A, Kumar Y (2014). Cellular and molecular mechanisms in cancer immune escape: a comprehensive review. Expert Rev Clin Immunol 10(1): 41-62. doi: 10.1586/1744666X.2014.865519

23. Hanahan D, Weinberg RA (2011). Hallmarks of cancer: the next generation. Cell 144(5): 646-674. doi: 10.1016/j.cell.2011.02.013

24. Prendergast GC, Smith C, Thomas S, Mandik-Nayak L, LauryKleintop L, Metz R, Muller AJ (2014). Indoleamine 2,3-dioxygenase pathways of pathogenic inflammation and immune escape in cancer. Cancer Immunol Immunother 63(7): 721-735. doi: 10.1007/s00262014-1549-4
25. Banh A, Zhang J, Cao H, Bouley DM, Kwok S, Kong C, Giaccia AJ, Koong AC, Le QT (2011). Tumor galectin-1 mediates tumor growth and metastasis through regulation of T-cell apoptosis. Cancer Res 71(13): 4423-4431. doi: 10.1158/0008-5472.CAN-10-4157

26. Grimm M, Kim M, Rosenwald A, von Raden BH, von Rahden B, Tsaur I, Meier E, Heemann U, Germer CT, Gasser M, Waaga-Gasser AM (2010). Tumour-mediated TRAIL-Receptor expression indicates effective apoptotic depletion of infiltrating CD8+ immune cells in clinical colorectal cancer. Eur J Cancer 46(12): 2314-2323. doi: 10.1016/j.ejca.2010.05.025

27. Zhu J, Powis de Tenbossche CG, Cané S, Colau D, van Baren N, Lurquin C, Schmitt-Verhulst AM, Liljeström P, Uyttenhove C, Van den Eynde BJ (2017). Resistance to cancer immunotherapy mediated by apoptosis of tumor-infiltrating lymphocytes. Nat Commun 8(1): 1404. doi: 10.1038/s41467-017-00784-1

28. Viale A, Pettazzoni $P$, Lyssiotis CA, Ying $H$, Sánchez $N$, Marchesini M, Carugo A, Green T, Seth S, Giuliani V, Kost-Alimova M, Muller F, Colla S, Nezi L, Genovese G, Deem AK, Kapoor A, Yao W, Brunetto E, Kang Y, Yuan M, Asara JM, Wang YA, Heffernan TP, Kimmelman AC, Wang $\mathrm{H}$, Fleming JB, Cantley LC, DePinho RA, Draetta GF (2014). Oncogene ablation-resistant pancreatic cancer cells depend on mitochondrial function. Nature 514(7524): 628-632. doi: $10.1038 /$ nature 13611

29. WARBURG O (1956). On the origin of cancer cells. Science 123(3191): 309-314. doi: 10.1126/science.123.3191.309

30. Wang $R$, Dillon $C P$, Shi LZ, Milasta $S$, Carter $R$, Finkelstein $D$, McCormick LL, Fitzgerald P, Chi H, Munger J, Green DR (2011). The transcription factor Myc controls metabolic reprogramming upon $\mathrm{T}$ lymphocyte activation. Immunity 35(6): 871-882. doi: 10.1016/j.immuni.2011.09.021

31. Chang CH, Qiu J, O'Sullivan D, Buck MD, Noguchi T, Curtis JD, Chen $Q$, Gindin M, Gubin MM, van der Windt GJ, Tonc E, Schreiber RD, Pearce EJ, Pearce EL (2015). Metabolic Competition in the Tumor Microenvironment Is a Driver of Cancer Progression. Cell 162(6): 1229-1241. doi: 10.1016/j.cell.2015.08.016

32. Fischer K, Hoffmann P, Voelkl S, Meidenbauer N, Ammer J, Edinger M, Gottfried E, Schwarz S, Rothe G, Hoves S, Renner K, Timischl B, Mackensen A, Kunz-Schughart L, Andreesen R, Krause SW, Kreutz M (2007). Inhibitory effect of tumor cell-derived lactic acid on human $T$ cells. Blood 109(9): 3812-3819. doi: 10.1182/blood-2006-07-035972

33. Chang $\mathrm{CH}$, Curtis JD, Maggi LB, Faubert B, Villarino AV, O'Sullivan D, Huang SC, van der Windt GJ, Blagih J, Qiu J, Weber JD, Pearce EJ, Jones RG, Pearce EL (2013). Posttranscriptional control of T cell effector function by aerobic glycolysis. Cell 153(6): 1239-1251. doi: 10.1016/j.cell.2013.05.016

34. Alsaab HO, Sau S, Alzhrani R, Tatiparti K, Bhise K, Kashaw SK, Iyer AK (2017). PD-1 and PD-L1 Checkpoint Signaling Inhibition for Cancer Immunotherapy: Mechanism, Combinations, and Clinical Outcome. Front Pharmacol 8(561. doi: 10.3389/fphar.2017.00561

35. Rozali EN, Hato SV, Robinson BW, Lake RA, Lesterhuis WJ (2012). Programmed death ligand 2 in cancer-induced immune suppression. Clin Dev Immunol 2012(656340. doi: 10.1155/2012/656340

36. Parry RV, Chemnitz JM, Frauwirth KA, Lanfranco AR, Braunstein I, Kobayashi SV, Linsley PS, Thompson CB, Riley JL (2005). CTLA-4 and $\mathrm{PD}-1$ receptors inhibit T-cell activation by distinct mechanisms. Mol Cell Biol 25(21): 9543-9553. doi: 10.1128/MCB.25.21.9543-9553.2005

37. Michalek RD, Gerriets VA, Jacobs SR, Macintyre AN, Maclver NJ, Mason EF, Sullivan SA, Nichols AG, Rathmell JC (2011). Cutting edge: distinct glycolytic and lipid oxidative metabolic programs are essential for effector and regulatory CD4+ T cell subsets. J Immunol 186(6): 3299-3303. doi: 10.4049/jimmunol.1003613 
38. Procaccini C, Carbone F, Di Silvestre D, Brambilla F, De Rosa V, Galgani M, Faicchia D, Marone G, Tramontano D, Corona M, Alviggi C, Porcellini A, La Cava A, Mauri P, Matarese G (2016). The Proteomic Landscape of Human Ex Vivo Regulatory and Conventional T Cells Reveals Specific Metabolic Requirements. Immunity 44(3): 712. doi: 10.1016/j.immuni.2016.02.022

39. Angelin A, Gil-de-Gómez L, Dahiya S, Jiao J, Guo L, Levine $\mathrm{MH}$, Wang Z, Quinn WJ, Kopinski PK, Wang L, Akimova T, Liu Y, Bhatti TR, Han R, Laskin BL, Baur JA, Blair IA, Wallace DC, Hancock WW, Beier UH (2017). Foxp3 Reprograms $T$ Cell Metabolism to Function in LowGlucose, High-Lactate Environments. Cell Metab 25(6): 12821293.e1287. doi: 10.1016/j.cmet.2016.12.018

40. Motz GT, Santoro SP, Wang LP, Garrabrant T, Lastra RR, Hagemann IS, Lal P, Feldman MD, Benencia F, Coukos G (2014). Tumor endothelium FasL establishes a selective immune barrier promoting tolerance in tumors. Nat Med 20(6): 607-615. doi: 10.1038/nm.3541

41. Singel KL, Segal BH (2016). Neutrophils in the tumor microenvironment: trying to heal the wound that cannot heal. Immunol Rev 273(1): 329-343. doi: 10.1111/imr.12459

42. Carretero R, Sektioglu IM, Garbi N, Salgado OC, Beckhove P, Hammerling GJ (2015). Eosinophils orchestrate cancer rejection by normalizing tumor vessels and enhancing infiltration of CD8(+) T cells. Nat Immunol 16(6): 609-617. doi: 10.1038/ni.3159

43. Sektioglu IM, Carretero R, Bulbuc N, Bald T, Tuting T, Rudensky AY Hammerling GJ (2017). Basophils Promote Tumor Rejection via Chemotaxis and Infiltration of CD8+ T Cells. Cancer Res 77(2): 291-302. doi: 10.1158/0008-5472.CAN-16-0993

44. Ugel S, De Sanctis F, Mandruzzato S, Bronte V (2015). Tumorinduced myeloid deviation: when myeloid-derived suppressor cells meet tumor-associated macrophages. J Clin Invest 125(9): 3365-3376. doi: $10.1172 / \mathrm{JCl} 80006$

45. Geiger R, Rieckmann JC, Wolf $T$, Basso C, Feng $Y$, Fuhrer T, Kogadeeva M, Picotti P, Meissner F, Mann M, Zamboni N, Sallusto F, Lanzavecchia A (2016). L-Arginine Modulates T Cell Metabolism and Enhances Survival and Anti-tumor Activity. Cell 167(3): 829-842 e813. doi: 10.1016/j.cell.2016.09.031

46. Spranger S, Spaapen RM, Zha Y, Williams J, Meng Y, Ha TT, Gajewski TF (2013). Up-regulation of PD-L1, IDO, and T(regs) in the melanoma tumor microenvironment is driven by CD8(+) T cells. Sci Transl Med 5(200): 200ra116. doi: 10.1126/scitranslmed.3006504

47. Sakuishi K, Jayaraman P, Behar SM, Anderson AC, Kuchroo VK (2011). Emerging Tim-3 functions in antimicrobial and tumor immunity. Trends Immunol 32(8): 345-349. doi: 10.1016/j.it.2011.05.003

48. De Bock K, Cauwenberghs S, Carmeliet P (2011). Vessel abnormalization: another hallmark of cancer? Molecular mechanisms and therapeutic implications. Curr Opin Genet Dev 21(1): 73-79. doi: 10.1016/j.gde.2010.10.008

49. Hanahan D, Folkman J (1996). Patterns and emerging mechanisms of the angiogenic switch during tumorigenesis. Cell 86(3): 353-364. doi: 10.1016/s0092-8674(00)80108-7

50. Koshikawa N, lyozumi A, Gassmann M, Takenaga K (2003). Constitutive upregulation of hypoxia-inducible factor-1alpha mRNA occurring in highly metastatic lung carcinoma cells leads to vascular endothelial growth factor overexpression upon hypoxic exposure. Oncogene 22(43): 6717-6724. doi: 10.1038/sj.onc.1206765

51. Guillaumond F, Leca J, Olivares O, Lavaut MN, Vidal N, Berthezene P, Dusetti NJ, Loncle C, Calvo E, Turrini O, lovanna JL, Tomasini R, Vasseur $S$ (2013). Strengthened glycolysis under hypoxia supports tumor symbiosis and hexosamine biosynthesis in pancreatic adenocarcinoma. Proc Natl Acad Sci U S A 110(10): 3919-3924. doi 10.1073/pnas.1219555110
52. Shields JD, Borsetti M, Rigby $H$, Harper SJ, Mortimer PS, Levick JR, Orlando A, Bates DO (2004). Lymphatic density and metastatic spread in human malignant melanoma. Br J Cancer 90(3): 693-700. doi: 10.1038/sj.bjc.6601571

53. Farnsworth RH, Karnezis $T$, Shayan R, Matsumoto $M$, Nowell $\mathrm{CJ}$, Achen MG, Stacker SA (2011). A role for bone morphogenetic protein 4 in lymph node vascular remodeling and primary tumor growth. Cancer Res 71(20): 6547-6557. doi: 10.1158/0008-5472.CAN-11-0200

54. Slaney CY, Kershaw MH, Darcy PK (2014). Trafficking of T cells into tumors. Cancer Res 74(24): 7168-7174. doi: 10.1158/0008-5472.CAN14-2458

55. Mauldin IS, Wages NA, Stowman AM, Wang E, Smolkin ME, Olson WC, Deacon DH, Smith KT, Galeassi NV, Chianese-Bullock KA, Denge LT, Marincola FM, Petroni GR, Mullins DW, Slingluff CL, Jr. (2016). Intratumoral interferon-gamma increases chemokine production but fails to increase $T$ cell infiltration of human melanoma metastases. Cancer Immunol Immunother 65(10): 1189-1199. doi: 10.1007/s00262-016-1881-y

56. Neumann AK, Yang J, Biju MP, Joseph SK, Johnson RS, Haase VH Freedman BD, Turka LA (2005). Hypoxia inducible factor 1 alpha regulates $\mathrm{T}$ cell receptor signal transduction. Proc Natl Acad Sci U S A 102(47): 17071-17076. doi: 10.1073/pnas.0506070102

57. Kondoh M, Ohga N, Akiyama K, Hida Y, Maishi N, Towfik AM, Inoue $\mathrm{N}$, Shindoh M, Hida K (2013). Hypoxia-induced reactive oxygen species cause chromosomal abnormalities in endothelial cells in the tumor microenvironment. PLoS One 8(11): e80349. doi: 10.1371/journal.pone.0080349

58. Barsoum IB, Smallwood CA, Siemens DR, Graham CH (2014). A mechanism of hypoxia-mediated escape from adaptive immunity in cancer cells. Cancer Res 74(3): 665-674. doi: 10.1158/0008-5472.CAN13-0992

59. Barker HE, Chang J, Cox TR, Lang G, Bird D, Nicolau M, Evans HR, Gartland A, Erler JT (2011). LOXL2-mediated matrix remodeling in metastasis and mammary gland involution. Cancer Res 71(5): 15611572. doi: 10.1158/0008-5472.CAN-10-2868

60. Zhu J, Liang L, Jiao Y, Liu L, Alliance US-CPS-O (2015). Enhanced invasion of metastatic cancer cells via extracellular matrix interface. PLoS One 10(2): e0118058. doi: 10.1371/journal.pone.0118058

61. Del Bufalo F, Manzo T, Hoyos V, Yagyu S, Caruana I, Jacot J, Benavides $O$, Rosen D, Brenner MK (2016). 3D modeling of human cancer: A PEG-fibrin hydrogel system to study the role of tumor microenvironment and recapitulate the in vivo effect of oncolytic adenovirus. Biomaterials 84(76-85. doi: 10.1016/j.biomaterials.2016.01.030

62. Levental KR, Yu H, Kass L, Lakins JN, Egeblad M, Erler JT, Fong SF, Csiszar K, Giaccia A, Weninger W, Yamauchi M, Gasser DL, Weaver VM (2009). Matrix crosslinking forces tumor progression by enhancing integrin signaling. Cell 139(5): 891-906. doi: 10.1016/j.cell.2009.10.027

63. Murakami N, Riella LV (2014). Co-inhibitory pathways and their importance in immune regulation. Transplantation 98(1): 3-14. doi: 10.1097/TP.0000000000000169

64. Maj T, Wei S, Welling T, Zou W (2013). T cells and costimulation in cancer. Cancer J 19(6): 473-482. doi: 10.1097/PPO.0000000000000002

65. Kim PS, Ahmed R (2010). Features of responding T cells in cancer and chronic infection. Curr Opin Immunol 22(2): 223-230. doi 10.1016/j.coi.2010.02.005

66. Baitsch L, Fuertes-Marraco SA, Legat A, Meyer C, Speiser DE (2012). The three main stumbling blocks for anticancer $T$ cells. Trends Immunol 33(7): 364-372. doi: 10.1016/j.it.2012.02.006 
67. Driessens G, Kline J, Gajewski TF (2009). Costimulatory and coinhibitory receptors in anti-tumor immunity. Immunol Rev 229(1): 126144. doi: 10.1111/j.1600-065X.2009.00771.x

68. Fourcade J, Sun Z, Benallaoua M, Guillaume P, Luescher IF, Sander C, Kirkwood JM, Kuchroo V, Zarour HM (2010). Upregulation of Tim-3 and PD-1 expression is associated with tumor antigen-specific CD8+ T cell dysfunction in melanoma patients. J Exp Med 207(10): 2175-2186. doi: 10.1084/jem.20100637

69. Fourcade J, Sun Z, Pagliano O, Guillaume P, Luescher IF, Sander C, Kirkwood JM, Olive D, Kuchroo V, Zarour HM (2012). CD8(+) T cells specific for tumor antigens can be rendered dysfunctional by the tumor microenvironment through upregulation of the inhibitory receptors BTLA and PD-1. Cancer Res 72(4): 887-896. doi: 10.1158/0008-5472.CAN-11-2637

70. Chauvin JM, Pagliano O, Fourcade J, Sun Z, Wang H, Sander C, Kirkwood JM, Chen TH, Maurer M, Korman AJ, Zarour HM (2015). TIGIT and PD-1 impair tumor antigen-specific CD8(+) T cells in melanoma patients. J Clin Invest 125(5): 2046-2058. doi: 10.1172/JCI80445

71. Wherry EJ, Ha SJ, Kaech SM, Haining WN, Sarkar S, Kalia V, Subramaniam S, Blattman JN, Barber DL, Ahmed R (2007). Molecular signature of CD8+ T cell exhaustion during chronic viral infection. Immunity 27(4): 670-684. doi: 10.1016/j.immuni.2007.09.006

72. Angelosanto JM, Blackburn SD, Crawford A, Wherry EJ (2012). Progressive loss of memory $T$ cell potential and commitment to exhaustion during chronic viral infection. J Virol 86(15): 8161-8170. doi: 10.1128/JVI.00889-12

73. Zhu S, Lin J, Qiao G, Wang X, Xu Y (2016). Tim-3 identifies exhausted follicular helper $T$ cells in breast cancer patients. Immunobiology 221(9): 986-993. doi: 10.1016/j.imbio.2016.04.005

74. Giordano M, Henin C, Maurizio J, Imbratta C, Bourdely P, Buferne M, Baitsch L, Vanhille L, Sieweke $\mathrm{MH}$, Speiser DE, Auphan-Anezin N, Schmitt-Verhulst AM, Verdeil G (2015). Molecular profiling of CD8 T cells in autochthonous melanoma identifies Maf as driver of exhaustion. EMBO J 34(15): 2042-2058. doi: 10.15252/embj.201490786

75. Japp AS, Kursunel MA, Meier S, Mälzer JN, Li X, Rahman NA, Jekabsons W, Krause H, Magheli A, Klopf C, Thiel A, Frentsch M (2015). Dysfunction of PSA-specific CD8+ T cells in prostate cancer patients correlates with CD38 and Tim-3 expression. Cancer Immunol Immunother 64(11): 1487-1494. doi: 10.1007/s00262-015-1752-y

76. Goh C, Narayanan S, Hahn YS (2013). Myeloid-derived suppressor cells: the dark knight or the joker in viral infections? Immunol Rev 255(1): 210-221. doi: 10.1111/imr.12084

77. Holderried TA, Lang PA, Kim HJ, Cantor H (2013). Genetic disruption of CD8+ Treg activity enhances the immune response to viral infection. Proc Natl Acad Sci U S A 110(52): 21089-21094. doi: 10.1073/pnas.1320999110

78. Lee S, Margolin K (2011). Cytokines in cancer immunotherapy. Cancers (Basel) 3(4): 3856-3893. doi: 10.3390/cancers3043856

79. Eil R, Vodnala SK, Clever D, Klebanoff CA, Sukumar M, Pan JH, Palmer DC, Gros A, Yamamoto TN, Patel SJ, Guittard GC, Yu Z, Carbonaro V, Okkenhaug K, Schrump DS, Linehan WM, Roychoudhuri R, Restifo NP (2016). Ionic immune suppression within the tumour microenvironment limits T cell effector function. Nature 537(7621): 539543. doi: 10.1038/nature19364

80. Chimote AA, Hajdu P, Sfyris AM, Gleich BN, Wise-Draper T, Casper KA, Conforti L (2017). Kv1.3 Channels Mark Functionally Competent CD8+ Tumor-Infiltrating Lymphocytes in Head and Neck Cancer. Cancer Res 77(1): 53-61. doi: 10.1158/0008-5472.CAN-16-2372

81. Zlotnik A (2004). Chemokines in neoplastic progression. Semin Cancer Biol 14(3): 181-185. doi: 10.1016/j.semcancer.2003.10.004
82. Viola A, Sarukhan A, Bronte V, Molon B (2012). The pros and cons of chemokines in tumor immunology. Trends Immunol 33(10): 496504. doi: 10.1016/j.it.2012.05.007

83. Gorbachev AV, Fairchild RL (2014). Regulation of chemokine expression in the tumor microenvironment. Crit Rev Immunol 34(2): 103-120. doi: 10.1615/critrevimmunol.2014010062

84. Feig C, Jones JO, Kraman M, Wells RJ, Deonarine A, Chan DS, Connell CM, Roberts EW, Zhao Q, Caballero OL, Teichmann SA, Janowitz T, Jodrell DI, Tuveson DA, Fearon DT (2013). Targeting CXCL12 from FAPexpressing carcinoma-associated fibroblasts synergizes with anti-PDL1 immunotherapy in pancreatic cancer. Proc Natl Acad Sci U S A 110(50): 20212-20217. doi: 10.1073/pnas.1320318110

85. Molon B, Ugel S, Del Pozzo F, Soldani C, Zilio S, Avella D, De Palma A, Mauri P, Monegal A, Rescigno M, Savino B, Colombo P, Jonjic N, Pecanic S, Lazzarato L, Fruttero R, Gasco A, Bronte V, Viola A (2011). Chemokine nitration prevents intratumoral infiltration of antigenspecific $T$ cells. J Exp Med 208(10): 1949-1962. doi: 10.1084/jem.20101956

86. Caruana I, Savoldo B, Hoyos V, Weber G, Liu H, Kim ES, Ittmann MM, Marchetti D, Dotti G (2015). Heparanase promotes tumor infiltration and antitumor activity of CAR-redirected T lymphocytes. Nat Med 21(5): 524-529. doi: 10.1038/nm.3833

87. Alizadeh D, Trad M, Hanke NT, Larmonier CB, Janikashvili N, Bonnotte $B$, Katsanis E, Larmonier N (2014). Doxorubicin eliminates myeloid-derived suppressor cells and enhances the efficacy of adoptive $\mathrm{T}$ cell transfer in breast cancer. Cancer Res 74(1): 104-118. doi: 10.1158/0008-5472.CAN-13-1545

88. Machiels JP, Reilly RT, Emens LA, Ercolini AM, Lei RY, Weintraub D, Okoye FI, Jaffee EM (2001). Cyclophosphamide, doxorubicin, and paclitaxel enhance the antitumor immune response of granulocyte/macrophage-colony stimulating factor-secreting whole-cell vaccines in HER-2/neu tolerized mice. Cancer Res 61(9): 3689-3697. PMID: 11325840

89. Soriano JL, Batista N, Santiesteban E, Lima M, Gonzalez J, Garcia R, Zarza Y, Lopez MV, Rodriguez M, Loys JL, Montejo N, Aguirre F, Macias A, Vazquez AM (2011). Metronomic Cyclophosphamide and Methotrexate Chemotherapy Combined with 1E10 Anti-Idiotype Vaccine in Metastatic Breast Cancer. Int J Breast Cancer 2011(710292. doi: 10.4061/2011/710292

90. Wang Z, Pratts SG, Zhang H, Spencer PJ, Yu R, Tonsho M, Shah JA, Tanabe T, Powell HR, Huang CA, Madsen JC, Sachs DH, Wang Z (2016). Treg depletion in non-human primates using a novel diphtheria toxinbased anti-human CCR4 immunotoxin. Mol Oncol 10(4): 553-565. doi: 10.1016/j.molonc.2015.11.008

91. Hodi FS, O'Day SJ, McDermott DF, Weber RW, Sosman JA, Haanen JB, Gonzalez R, Robert C, Schadendorf D, Hassel JC, Akerley W, van den Eertwegh AJ, Lutzky J, Lorigan P, Vaubel JM, Linette GP, Hogg D, Ottensmeier $\mathrm{CH}$, Lebbe C, Peschel C, Quirt I, Clark JI, Wolchok JD, Weber JS, Tian J, Yellin MJ, Nichol GM, Hoos A, Urba WJ (2010). Improved survival with ipilimumab in patients with metastatic melanoma. N Engl J Med 363(8): 711-723. doi: 10.1056/NEJMoa1003466

92. Wu L, Yun Z, Tagawa T, Rey-McIntyre K, de Perrot M (2012). CTLA4 blockade expands infiltrating $T$ cells and inhibits cancer cell repopulation during the intervals of chemotherapy in murine mesothelioma. Mol Cancer Ther 11(8): 1809-1819. doi: 10.1158/1535-7163.MCT-111014

93. Griffioen AW (2008). Anti-angiogenesis: making the tumor vulnerable to the immune system. Cancer Immunol Immunother 57(10): 1553-1558. doi: 10.1007/s00262-008-0524-3

94. Bocca P, Carlo ED, Caruana I, Emionite L, Cilli M, De Angelis B, Quintarelli C, Pezzolo A, Raffaghello L, Morandi F, Locatelli F, Pistoia V, Prigione I (2017). Bevacizumab-mediated tumor vasculature remodel- 
ling improves tumor infiltration and antitumor efficacy of GD2-CAR T cells in a human neuroblastoma preclinical model. Oncoimmunology 7(1): e1378843. doi: 10.1080/2162402X.2017.1378843

95. Hoyos V, Del Bufalo F, Yagyu S, Ando M, Dotti G, Suzuki M, Bouchier-Hayes L, Alemany R, Brenner MK (2015). Mesenchymal Stromal Cells for Linked Delivery of Oncolytic and Apoptotic Adenoviruses to Non-small-cell Lung Cancers. Mol Ther 23(9): 1497-1506. doi: 10.1038/mt.2015.110

96. Nishio N, Diaconu I, Liu H, Cerullo V, Caruana I, Hoyos V, BouchierHayes L, Savoldo B, Dotti G (2014). Armed oncolytic virus enhances immune functions of chimeric antigen receptor-modified $T$ cells in solid tumors. Cancer Res 74(18): 5195-5205. doi: 10.1158/00085472. CAN-14-0697

97. Caruana I, Weber G, Ballard BC, Wood MS, Savoldo B, Dotti G (2015). K562-Derived Whole-Cell Vaccine Enhances Antitumor Responses of CAR-Redirected Virus-Specific Cytotoxic T Lymphocytes In Vivo. Clin Cancer Res 21(13): 2952-2962. doi: 10.1158/1078 0432.CCR-14-2998

98. Couzin-Frankel J (2013). Breakthrough of the year 2013. Cancer immunotherapy. Science 342(6165): 1432-1433. doi: 10.1126/science.342.6165.1432

99. Porter DL, Levine BL, Kalos M, Bagg A, June CH (2011). Chimeric antigen receptor-modified $\mathrm{T}$ cells in chronic lymphoid leukemia. $\mathbf{N}$ Engl J Med 365(8): 725-733. doi: 10.1056/NEJMoa1103849

100. Topalian SL, Hodi FS, Brahmer JR, Gettinger SN, Smith DC, McDermott DF, Powderly JD, Carvajal RD, Sosman JA, Atkins MB, Leming PD, Spigel DR, Antonia SJ, Horn L, Drake CG, Pardoll DM, Chen L, Sharfman WH, Anders RA, Taube JM, McMiller TL, Xu H, Korman AJ, Jure-Kunkel M, Agrawal S, McDonald D, Kollia GD, Gupta A, Wigginton JM, Sznol M (2012). Safety, activity, and immune correlates of anti-PD1 antibody in cancer. N Engl J Med 366(26): 2443-2454. doi: 10.1056/NEJMoa1200690

101. Brahmer JR, Tykodi SS, Chow LQ, Hwu WJ, Topalian SL, Hwu P, Drake CG, Camacho LH, Kauh J, Odunsi K, Pitot HC, Hamid O, Bhatia S, Martins R, Eaton K, Chen S, Salay TM, Alaparthy S, Grosso JF, Korman AJ, Parker SM, Agrawal S, Goldberg SM, Pardoll DM, Gupta A, Wigginton JM (2012). Safety and activity of anti-PD-L1 antibody in patients with advanced cancer. N Engl J Med 366(26): 2455-2465. doi: 10.1056/NEJMoa1200694

102. Weber G, Caruana I, Rouce RH, Barrett AJ, Gerdemann U, Leen AM, Rabin KR, Bollard CM (2013). Generation of tumor antigenspecific $T$ cell lines from pediatric patients with acute lymphoblastic leukemia--implications for immunotherapy. Clin Cancer Res 19(18): 5079-5091. doi: 10.1158/1078-0432.CCR-13-0955

103. Weber G, Gerdemann U, Caruana I, Savoldo B, Hensel NF, Rabin KR, Shpall EJ, Melenhorst JJ, Leen AM, Barrett AJ, Bollard CM (2013). Generation of multi-leukemia antigen-specific $T$ cells to enhance the graft-versus-leukemia effect after allogeneic stem cell transplant. Leukemia 27(7): 1538-1547. doi: 10.1038/leu.2013.66

104. Holohan C, Van Schaeybroeck S, Longley DB, Johnston PG (2013). Cancer drug resistance: an evolving paradigm. Nat Rev Cancer 13(10): 714-726. doi: 10.1038/nrc3599

105. Klemm F, Joyce JA (2015). Microenvironmental regulation of therapeutic response in cancer. Trends Cell Biol 25(4): 198-213. doi: 10.1016/j.tcb.2014.11.006

106. Devaud C, John LB, Westwood JA, Darcy PK, Kershaw MH (2013). Immune modulation of the tumor microenvironment for enhancing cancer immunotherapy. Oncoimmunology 2(8): e25961. doi: 10.4161/onci. 25961
107. Oelkrug C, Ramage JM (2014). Enhancement of T cell recruitment and infiltration into tumours. Clin Exp Immunol 178(1): 1-8. doi: 10.1111/cei.12382

108. Tang H, Wang Y, Chlewicki LK, Zhang Y, Guo J, Liang W, Wang J, Wang X, Fu YX (2016). Facilitating T Cell Infiltration in Tumor Microenvironment Overcomes Resistance to PD-L1 Blockade. Cancer Cell 30(3): 500. doi: 10.1016/j.ccell.2016.08.011

109. Allen F, Bobanga ID, Rauhe P, Barkauskas D, Teich N, Tong C, Myers J, Huang AY (2018). CCL3 augments tumor rejection and enhances CD8. Oncoimmunology 7(3): e1393598. doi: 10.1080/2162402X.2017.1393598

110. Wolchok JD, Kluger H, Callahan MK, Postow MA, Rizvi NA, Lesokhin AM, Segal NH, Ariyan CE, Gordon RA, Reed K, Burke MM, Caldwell A, Kronenberg SA, Agunwamba BU, Zhang X, Lowy I, Inzunza HD, Feely W, Horak CE, Hong Q, Korman AJ, Wigginton JM, Gupta A, Sznol M (2013). Nivolumab plus ipilimumab in advanced melanoma. $\mathbf{N}$ Engl J Med 369(2): 122-133. doi: 10.1056/NEJMoa1302369

111. Catakovic K, Klieser E, Neureiter D, Geisberger R (2017). T cell exhaustion: from pathophysiological basics to tumor immunotherapy. Cell Commun Signal 15(1): 1. doi: 10.1186/s12964-016-0160-z

112. Cha $E$, Klinger $M$, Hou $Y$, Cummings $C$, Ribas $A$, Faham $M$, Fong $L$ (2014). Improved survival with $T$ cell clonotype stability after antiCTLA-4 treatment in cancer patients. Sci Transl Med 6(238): 238ra270. doi: 10.1126/scitranslmed.3008211

113. Goldberg MV, Drake CG (2011). LAG-3 in Cancer Immunotherapy. Curr Top Microbiol Immunol 344(269-278. doi: 10.1007/82_2010_114

114. Melero I, Hervas-Stubbs S, Glennie M, Pardoll DM, Chen L (2007). Immunostimulatory monoclonal antibodies for cancer therapy. Nat Rev Cancer 7(2): 95-106. doi: 10.1038/nrc2051

115. Caruana I, Diaconu I, Dotti G (2014). From monoclonal antibodies to chimeric antigen receptors for the treatment of human malignancies. Semin Oncol 41(5): 661-666. doi 10.1053/j.seminoncol.2014.08.005

116. Töpfer K, Cartellieri M, Michen S, Wiedemuth R, Müller N, Lindemann D, Bachmann M, Füssel M, Schackert G, Temme A (2015). DAP12-based activating chimeric antigen receptor for NK cell tumor immunotherapy. J Immunol 194(7): 3201-3212. doi: 10.4049/jimmunol.1400330

117. Demoulin B, Cook WJ, Murad J, Graber DJ, Sentman ML, Lonez C, Gilham DE, Sentman CL, Agaugue S (2017). Exploiting natural killer group 2D receptors for CAR T-cell therapy. Future Oncol 13(18): 15931605. doi: 10.2217/fon-2017-0102

118. Quintarelli C, Orlando D, Boffa I, Guercio M, Polito VA, Petretto A, Lavarello C, Sinibaldi M, Weber G, Del Bufalo F, Giorda E, Scarsella M, Petrini S, Pagliara D, Locatelli F, De Angelis B, Caruana I (2018). Choice of costimulatory domains and of cytokines determines CAR T-cell activity in neuroblastoma. Oncolmmunology: e1433518. doi $10.1080 / 2162402 \times .2018 .1433518$

119. Grupp SA, Kalos M, Barrett D, Aplenc R, Porter DL, Rheingold SR, Teachey DT, Chew A, Hauck B, Wright JF, Milone MC, Levine BL, June $\mathrm{CH}$ (2013). Chimeric antigen receptor-modified T cells for acute lymphoid leukemia. N Engl J Med 368(16): 1509-1518. doi: 10.1056/NEJMoa1215134

120. Pule MA, Savoldo B, Myers GD, Rossig C, Russell HV, Dotti G, Huls $\mathrm{MH}$, Liu E, Gee AP, Mei Z, Yvon E, Weiss HL, Liu H, Rooney CM, Heslop $H E$, Brenner MK (2008). Virus-specific T cells engineered to coexpress tumor-specific receptors: persistence and antitumor activity in individuals with neuroblastoma. Nat Med 14(11): 1264-1270. doi: 10.1038/nm.1882

121. Adachi K, Kano Y, Nagai T, Okuyama N, Sakoda Y, Tamada K (2018). IL-7 and CCL19 expression in CAR-T cells improves immune cell 
infiltration and CAR-T cell survival in the tumor. Nat Biotechnol 36(4): 346-351. doi: 10.1038/nbt.4086

122. Bol KF, Schreibelt G, Gerritsen WR, de Vries IJ, Figdor CG (2016). Dendritic Cell-Based Immunotherapy: State of the Art and Beyond. Clin Cancer Res 22(8): 1897-1906. doi: 10.1158/1078-0432.CCR-151399

123. Tureci O, Vormehr M, Diken M, Kreiter S, Huber C, Sahin U (2016). Targeting the Heterogeneity of Cancer with Individualized Neoepitope Vaccines. Clin Cancer Res 22(8): 1885-1896. doi: 10.1158/1078-0432.CCR-15-1509

124. Maus MV, June CH (2016). Making Better Chimeric Antigen Receptors for Adoptive T-cell Therapy. Clin Cancer Res 22(8): 1875-1884. doi: 10.1158/1078-0432.CCR-15-1433

125. Heczey A, Louis CU, Savoldo B, Dakhova O, Durett A, Grilley B, Liu H, Wu MF, Mei Z, Gee A, Mehta B, Zhang H, Mahmood N, Tashiro H, Heslop HE, Dotti G, Rooney CM, Brenner MK (2017). CAR T Cells Administered in Combination with Lymphodepletion and PD-1 Inhibition to Patients with Neuroblastoma. Mol Ther 25(9): 2214-2224. doi: 10.1016/j.ymthe.2017.05.012

126. Yang SC, Hillinger S, Riedl K, Zhang L, Zhu L, Huang M, Atianzar K, Kuo BY, Gardner B, Batra RK, Strieter RM, Dubinett SM, Sharma S (2004). Intratumoral administration of dendritic cells overexpressing CCL21 generates systemic antitumor responses and confers tumor immunity. Clin Cancer Res 10(8): 2891-2901. doi: 10.1158/10780432.ccr-03-0380

127. Shields JD, Kourtis IC, Tomei AA, Roberts JM, Swartz MA (2010). Induction of lymphoidlike stroma and immune escape by tumors that express the chemokine CCL21. Science 328(5979): 749-752. doi: $10.1126 /$ science. 1185837

128. Barreira da Silva R, Laird ME, Yatim N, Fiette L, Ingersoll MA, Albert ML (2015). Dipeptidylpeptidase 4 inhibition enhances lymphocyte trafficking, improving both naturally occurring tumor immunity and immunotherapy. Nat Immunol 16(8): 850-858. doi: 10.1038/ni.3201

129. Di Stasi A, De Angelis B, Rooney CM, Zhang L, Mahendravada A, Foster AE, Heslop HE, Brenner MK, Dotti G, Savoldo B (2009). T lymphocytes coexpressing CCR4 and a chimeric antigen receptor targeting CD30 have improved homing and antitumor activity in a Hodgkin tumor model. Blood 113(25): 6392-6402. doi: 10.1182/blood-2009-03209650

130. Campello S, Lacalle RA, Bettella M, Mañes S, Scorrano L, Viola A (2006). Orchestration of lymphocyte chemotaxis by mitochondrial dynamics. J Exp Med 203(13): 2879-2886. doi: 10.1084/jem.20061877

131. Jacobelli J, Estin Matthews M, Chen S, Krummel MF (2013). Activated $T$ cell trans-endothelial migration relies on myosin-IIA contractility for squeezing the cell nucleus through endothelial cell barriers. PLoS One 8(9): e75151. doi: 10.1371/journal.pone.0075151

132. Zhang $Y$, Kurupati R, Liu L, Zhou $X Y$, Zhang $G$, Hudaihed $A$, Filisio $F$, Giles-Davis W, Xu X, Karakousis GC, Schuchter LM, Xu W, Amaravadi R, Xiao M, Sadek N, Krepler C, Herlyn M, Freeman GJ, Rabinowitz JD, Ertl
HCJ (2017). Enhancing CD8. Cancer Cell 32(3): 377-391.e379. doi: 10.1016/j.ccell.2017.08.004

133. Palmer CS, Ostrowski M, Balderson B, Christian N, Crowe SM (2015). Glucose metabolism regulates T cell activation, differentiation, and functions. Front Immunol 6(1. doi: 10.3389/fimmu.2015.00001

134. van der Windt GJ, Everts B, Chang CH, Curtis JD, Freitas TC, Amiel E, Pearce EJ, Pearce EL (2012). Mitochondrial respiratory capacity is a critical regulator of $\mathrm{CD} 8+\mathrm{T}$ cell memory development. Immunity 36(1): 68-78. doi: 10.1016/j.immuni.2011.12.007

135. Buck MD, O'Sullivan D, Klein Geltink RI, Curtis JD, Chang CH, Sanin DE, Qiu J, Kretz O, Braas D, van der Windt GJ, Chen Q, Huang SC, O'Neill CM, Edelson BT, Pearce EJ, Sesaki H, Huber TB, Rambold AS, Pearce EL (2016). Mitochondrial Dynamics Controls T Cell Fate through Metabolic Programming. Cell 166(1): 63-76. doi: 10.1016/j.cell.2016.05.035

136. Scharping NE, Menk AV, Moreci RS, Whetstone RD, Dadey RE, Watkins SC, Ferris RL, Delgoffe GM (2016). The Tumor Microenvironment Represses T Cell Mitochondrial Biogenesis to Drive Intratumoral T Cell Metabolic Insufficiency and Dysfunction. Immunity 45(3): 701703. doi: 10.1016/j.immuni.2016.08.009

137. Qian W, Choi S, Gibson GA, Watkins SC, Bakkenist CJ, Van Houten $B$ (2012). Mitochondrial hyperfusion induced by loss of the fission protein Drp1 causes ATM-dependent G2/M arrest and aneuploidy through DNA replication stress. J Cell Sci 125(Pt 23): 5745-5757. doi: 10.1242/jcs.109769

138. Simula L, Nazio F, Campello S (2017). The mitochondrial dynamics in cancer and immune-surveillance. Semin Cancer Biol 47(29-42. doi: 10.1016/j.semcancer.2017.06.007

139. Russell JH, White CL, Loh DY, Meleedy-Rey P (1991). Receptorstimulated death pathway is opened by antigen in mature T cells. Proc Natl Acad Sci U S A 88(6): 2151-2155. doi: 10.1073/pnas.88.6.2151

140. Corrado M, Mariotti FR, Trapani L, Taraborrelli L, Nazio F, Cianfanelli V, Soriano ME, Schrepfer E, Cecconi F, Scorrano L, Campello $S$ (2016). Macroautophagy inhibition maintains fragmented mitochondria to foster T cell receptor-dependent apoptosis. EMBO 35(16): 1793-1809. doi: 10.15252/embj.201593727

141. Horton BL, Williams JB, Cabanov A, Spranger S, Gajewski TF (2018). Intratumoral CD8. Cancer Immunol Res 6(1): 14-24. doi: 10.1158/2326-6066.CIR-17-0249

142. Ebert PJ, Cheung J, Yang Y, McNamara E, Hong R, Moskalenko M, Gould SE, Maecker H, Irving BA, Kim JM, Belvin M, Mellman I (2016) MAP Kinase Inhibition Promotes $T$ Cell and Anti-tumor Activity in Combination with PD-L1 Checkpoint Blockade. Immunity 44(3): 609621. doi: 10.1016/j.immuni.2016.01.024

143. Dowling SD, Macian F (2018). Autophagy and T cell metabolism. Cancer Lett 419(20-26. doi: 10.1016/j.canlet.2018.01.033 